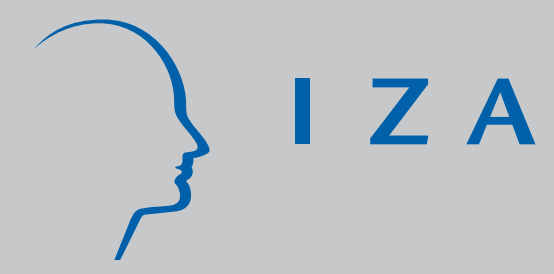

IZADP No. 2635

Trade Union Membership and Works Councils in West Germany

Laszlo Goerke

Markus Pannenberg

February 2007 


\title{
Trade Union Membership and Works Councils in West Germany
}

\author{
Laszlo Goerke \\ University of Tuebingen, \\ CESifo and IZA \\ Markus Pannenberg \\ University of Applied Sciences Bielefeld, \\ DIW Berlin and IZA

\section{Discussion Paper No. 2635 \\ February 2007}

\author{
IZA \\ P.O. Box 7240 \\ 53072 Bonn \\ Germany \\ Phone: +49-228-3894-0 \\ Fax: +49-228-3894-180 \\ E-mail: iza@iza.org
}

\begin{abstract}
Any opinions expressed here are those of the author(s) and not those of the institute. Research disseminated by IZA may include views on policy, but the institute itself takes no institutional policy positions.
\end{abstract}

The Institute for the Study of Labor (IZA) in Bonn is a local and virtual international research center and a place of communication between science, politics and business. IZA is an independent nonprofit company supported by Deutsche Post World Net. The center is associated with the University of Bonn and offers a stimulating research environment through its research networks, research support, and visitors and doctoral programs. IZA engages in (i) original and internationally competitive research in all fields of labor economics, (ii) development of policy concepts, and (iii) dissemination of research results and concepts to the interested public.

IZA Discussion Papers often represent preliminary work and are circulated to encourage discussion. Citation of such a paper should account for its provisional character. A revised version may be available directly from the author. 


\section{ABSTRACT}

\section{Trade Union Membership and Works Councils in West Germany}

The fraction of works councillors belonging to a trade union in Germany is much higher than union density among employees. If works councils represent the face of unions, union membership of employees should be related positively to the existence of works councils and their proximity to unions. Using data from the German Socio-Economic-Panel SOEP we find that (a) works councillors exhibit a higher probability of being a union member, (b) the mere existence of a works council within an establishment has no impact on union membership and (c) a $10 \%$ decrease in the average share of unionised works councillors coincides with a $10 \%$ fall in the probability of being a union member. Hence, the decline in the unionisation of works councillors and the fall in union density in West Germany are closely linked.

JEL Classification: J51, J53

Keywords: panel data, trade union membership, works councils

Corresponding author:

Markus Pannenberg

Department of Business and Economics

University of Applied Sciences Bielefeld

Universitätsstraße 25

D-33615 Bielefeld

Germany

E-mail: markus.pannenberg@fh-bielefeld.de 


\section{Introduction}

Why has trade union membership declined so dramatically in Germany since unification, dropping from approximately 13.7 million in 1990 to 8.5 million members in 2005? Age, sex, or occupational characteristics have consistently been found to explain an individual's probability of being a trade union member. However, these determinants of membership have not changed sufficiently over time to explain the dramatic decline in union density (Fitzenberger et al. 2006, Schnabel and Wagner 2006a). Among the explanatory variables subjected to empirical scrutiny, a particularly relevant one especially in the German industrial relations context has often been missing, namely the impact of employee representation at the establishment level.

While the influence of trade unions within establishments is often limited in Germany, there is a well-established system of employee representation at the level of the establishment, involving extensive information, consultation and co-determination rights. The Works Constitution Act makes works councils mandatory in all firms with at least five full-time employees. They are elected by the entire workforce. Since elections do not have to take place, unless employees request them, works council are not comprehensive. In the year 2000, works councils existed in 1 out of 6 establishments and covered about $53 \%$ of all German employees (Addison et al. 2004). Works councils are legally independent from trade unions and there is a fairly strict division of competences. Nevertheless, they are often closely related to trade unions since a large but declining majority of works councillors belong to trade unions. This suggests that the presence of works councils within an establishment can influence the decision of employees to become or be a member of a trade union. The conjecture is supported by the evidence on the development of union density and works council coverage over time, as the share of employees who are represented by works councils has also fallen.

Our hypothesis is that the existence of unionised works councils has a positive impact on the probability of an individual being a member of a trade union. We investigate this hypothesis using a representative survey of German residents (SOEP) which, inter alia, provides information on union density and representation by works councils for the years 2001 and 2003. We find that the fraction of unionised employees has declined by 1.7 percentage points from 2001 to 2003 to a level of $19.5 \%$. The share of works councillors who are members of a trade union has fallen more rapidly during that time span from about $68 \%$ to $56 \%$. Our

\footnotetext{
${ }^{1}$ Hassel (1999b) reports - for a non-representative sample - that the coverage of private sector employees by works councils declined from $50 \%$ to $40 \%$ from 1981 to 1994 .
} 
econometric analysis reveals that the proximity of works councils to trade unions, as measured by the fraction of unionised works councillors in an industry, is an important determinant of the individual membership decision. This implies that the strength of trade unions in Germany can be influenced by the share of unionised works councillors.

This paper is structured as follows: Section 2 substantiates our claim that the existence of works councils and, in particular, their proximity to trade unions can have an impact on the probability of an employee belonging to a union. To do so, the relationship between trade unions and works councils, primarily as regulated in the Works Constitution Act, is outlined first. Section 2.2 presents and discusses various arguments as to why works councils can influence the probability of trade union membership. The scarce and mostly indirect empirical evidence on this issue is summarised in Section 2.3. The focus of our exposition of the legal situation is on the private sector. This is because there is a different, albeit similar system of employee representation in the public sector. Hence, most arguments with respect to the impact of works councils on union membership in the private sector discussed in Section 2.2 also apply to the public sector. We accommodate this similarity by including public sector employees into our empirical analysis. In Section 3 the data and the empirical specifications are described. Section 4 contains descriptive evidence on the unionisation of employees and works councils in Germany. This section also presents the estimates of a single-equation model of trade union membership in which the information on the works councillor status of an individual and on the fraction of unionised works councillors in an industry enters as an exogenous explanatory variable. However, being a works councillor may be regarded as endogenous with respect to the individual decision to join a union, since unobservable individual abilities could influence both outcomes for example. As a check of robustness, the results from estimating a recursive simultaneous two-equation probit model of union membership and works councillorship are reported. They confirm the findings for the singleequation set-up. Section 5 summarises our results and concludes.

\section{On the Relationship Between Works Councils and Trade Unions}

\subsection{Works Councils and Trade Unions in the German System of Industrial Relations}

An extensive coverage by works councils in Germany dates back to 1920 when this institution was established by law. ${ }^{2}$ At that time works councils were introduced as a means to mitigate

\footnotetext{
${ }^{2}$ See Müller-Jentsch (1995), Addison (1999), and Addison et al. (2000) for descriptions of the development of co-determination in Germany and the current regulations of the Works Constitution Act in English.
} 
revolutionary desires. They were interpreted as an instrument of more reform-oriented unions, in order to further their influence at the plant level. Subsequent to World War II the dual interest representation through unions on the one hand and by works councils on the other hand was set up again, after being destroyed during the Third Reich. In particular, the Works Constitution Act (WCA, 'Betriebsverfassungsgesetz') of 1952 gave works councils ('Betriebsräte') important powers in social, personnel, and economic matters. Trade unions did not unanimously approve of this law. Firstly, some regional regulations which were replaced by the Works Constitution Act had involved substantially more co-determination rights than the WCA. Secondly, the Works Constitution Act emphasised the independence of works council from unions at the establishment level. In 1972, the Works Constitution Act was amended and co-determination rights of works councils in social and personnel matters were extended. But, as Müller-Jentsch (1995, p. 55) points out, "although the access of the unions to the workplace and their links with the works councils were improved, the formal independence of the councils and their exclusive jurisdiction over interest representation at the plant level were not affected."

According to today's version of the Works Constitution Act, which was last changed substantially in 2001, a works council must be established in any private sector company with at least five full-time employees at their request. Works councils are elected by all employees of age in an establishment, with the exception of so-called 'Leitende Angestellte', employees with substantial decision-making rights ( $\$ 5$ WCA). Works councils have co-determination rights on social issues and personnel matters and can veto hiring and dismissal decisions under fairly restrictive conditions. They also have information and consultation rights regarding matters of personnel planning and the organisation of the work process and information entitlements with respect to business matters. Some of these competences are limited to larger companies, with more than 20 or 100 full-time employees. The works council must act "in the spirit of mutual trust, taking into account effective collective bargaining agreements, and in collaboration with trade unions and employers associations present in the establishment, with the aim of furthering the well-being of employees and establishment" (own translation, WCA $\S 2$ ). To achieve this objective, union representatives must be granted access to the establishment. Unions can, in addition, propose candidates for works council elections $(\S 14)$ and bring cases to the labour court if employers do not adhere to their obligations detailed in the Works Constitution Act ( $\$ 23$ ). A union representative can participate in works council meetings if at least $25 \%$ of the works councillors make an according request ( $§ 31$ ). Moreover, employers and works councillors are obliged to prevent 
any discrimination, inter alia, with respect to union activity and attitudes towards trade unions (§ 75). While works council members are not allowed to call a strike in their role as councillors, they are not restricted in their union activities $(§ 74)$.

This brief survey of the role of unions as laid down in the Works Constitution Act indicates that trade unions and their representatives can play an important role for works council activities. However, their impact on a firm's decision is often contingent on cooperation of the works council. In this sense, works councils may be interpreted as gatekeepers who can regulate a trade union's influence at the establishment level.

\subsection{Works Councils and Trade Union Membership - Some Theoretical Considerations}

Joining a trade union can be interpreted as the decision to purchase a good. While the price of the good can be measured precisely - the union membership fee - the nature of the good which an employee acquires by joining a union is less well defined. Many of the benefits which trade unions confer on their members are not private but constitute semi-public or pure public goods. This is especially true in Germany where the Basic Law (Grundgesetz) guarantees the right to form coalitions between employees and employers. This basic right also entails the right not to join a coalition, such as a trade union. Accordingly, closed shops are illegal. This 'negative freedom to join a coalition' has also been interpreted by legal experts as ruling out differential wages or working conditions for otherwise alike union members and non-members. Accordingly wages, working conditions, employment protection rules and further consequences of trade unions activities benefit all employees within a firm or industry to which a collective bargaining agreement applies, irrespective of whether the person is a member of a trade union or not. This implies strong incentives to take a free ride on the benefits of trade union membership.

The last decades in the economic analysis of union membership have been characterised by the search for (quasi-) private goods which are uniquely related to trade union membership. ${ }^{3}$ Trade unions have been hypothesised to further employment protection solely for its members (Moreton 1998, 1999, Jones and McKenna 1984) and to be the sole provider of unemployment insurance (Holmlund and Lundborg 1999). Booth and Chatterji (1995, p. 346) further suggest "legal and pensions advice" and "grievance and promotion procedures" as private goods provided by unions. In addition to interpreting the excludable good in the above terms, trade union membership has also been viewed as providing a reputation which

\footnotetext{
${ }^{3}$ See Schnabel (2003) for a survey of the literature.
} 
enhances a member's utility directly due to an according societal norm. ${ }^{4}$ Since this reputation effect can only be obtained by a union member, social custom models can also help to overcome the free-rider problem.

Works councils have not played a role in this literature yet. This is to some extent surprising. We have identified five reasons for this neglect: Firstly, there is a close relationship between works councils and trade unions in Germany, as outlined above in Section 2.1. In addition, a large majority of works councillors have been or are trade union members (see Section 2.3 below for evidence). Therefore, industrial relations scholars have repeatedly interpreted works councils as decisive instruments of trade unions to recruit members within firms (Kotthoff 1979, p. 299, Streeck 1981, pp. 209 ff, Müller-Jentsch 1995, p. 61, Ebbinghaus and Visser 1999, Heery 2003). Taking this hypothesis as a starting point, Behrens (2005) estimates the probability that a works council will invest great effort in recruiting new union members. He finds a significantly positive impact of the union density of work councillors on this probability.

Secondly, works councillors can influence hiring and dismissal decisions (according to $\S \S 99$ - 103 WCA), as mentioned above. Given a proximity of works councillors to trade unions, their impact on employment decisions implies that works councillors may relate trade union membership of an individual to his or her future job prospects (Streeck 1981, p. 211, Hassel 1999a, pp. 142 ff). An according relation can exist, even if the Works Constitutions Act explicitly forbids discriminating non-members since such membership-based discrimination is difficult to substantiate. Thirdly, unionised works councils can enforce a norm or custom according to which free-riding on union membership is not desirable (Checchi and Visser 2005). This would suggest that the proximity of works councillors to trade unions, as manifested in their union membership, is conducive to an individual's probability of membership. Fourthly, trade union membership may be viewed as an experience good (Bryson and Gomez 2003, p. 74). The stronger the linkage between works councils and trade unions is, the more employees experience the effects of trade unions and the more likely it is that they also join.

Finally, union membership has been shown to increase with the existence of institutions which are closely related to trade unions, such as union unemployment insurance schemes. The so-called Ghent systems usually do not make membership compulsory in order to obtain

\footnotetext{
${ }^{4}$ Such models of trade union membership are based on the seminal paper by Akerlof (1980) and have been developed and employed by Booth and Chatterji (1993), Corneo (1993, 1995, 1997), Naylor and Cripps (1993), Naylor and Raaum (1993), Goerke (1997), and Goerke and Pannenberg (2004), inter alia.
} 
unemployment benefits. However, since the collection of unemployment insurance contributions and the paying out of benefits is organised by trade unions or by affiliated funds, the contact between employees and trade unions is much more intensive in countries with a Ghent system. This can enhance the incentives to join a union, or to remain a union member when becoming unemployed. The evidence for such a linkage comes primarily from cross-country studies on union density (Western 1993, 1997, pp. 55, 133, Ebbinghaus and Visser 1999, Blaschke 2000, Checchi and Visser 2005). Böckerman and Uusitalo (2006) show in addition that the emergence of independent, non-union related-unemployment insurance funds reduces union density in Finland.

The argument that being exposed to institutions close to trade unions enhances the probability of union membership can be extended to (unionised) works councils. In addition, such an institutional explanation of union membership decisions is amenable to an empirical investigation at the level of the individual employee because the experience of employees with the institution 'works council' varies greatly in Germany. This is the case because works council exist only in about every sixth company. Note though that works councils exist in an overwhelming majority of large firms. Therefore, the fraction of employees working in establishments in which there are works councils is much higher than $16 \%$ and amounts to around $61 \%$ in our data for $2001 .^{5}$

All of the above arguments referring to the positive impact of works councils on trade union membership are based on the assumption that works councillors are trade union members. If, however, that is not the case, works councillors will - presumably - not have an incentive to recruit employees as members or to enforce a social custom of trade union membership. Works councils which are dominated by non-union members may instead suggest to employees that non-membership is advantageous (Ebbinghaus and Visser 1999, Schnabel and Wagner 2006b). Furthermore, works councillors who abstain from unions are less likely to relate union membership with job prospects. A non-unionist works council may also function as a substitute for union activities at the establishment level and, hence, for union membership (Blaschke 2000, Visser 2002). Accordingly, a positive relationship between the incentives of being a trade union member and the existence and activities of works councils may be contingent on the proximity of works councils to trade unions.

\footnotetext{
${ }^{5}$ See Table A.2 in the Appendix. Addison et al. (2004) calculate a works council coverage of $54 \%$ in West Germany for 2000, using the IAB Establishment Panel.
} 


\subsection{Evidence on Works Councils and Union Membership}

The unionisation of works councillors, or more precisely the number of works councillors who are members of a trade union relative to all works councillors, can be used to measure the proximity between works councillors and trade unions. At an aggregate level, such information has been collected by the German Trade Union Confederation (Deutscher Gewerkschaftsbund, DGB) for firms in which at least one works councillor is a member of a trade union belonging to the DGB (Hassel 1999a, p. 143). In addition, the Institut der Deutschen Wirtschaft, a research institute associated with the German employers' associations, provides data on the union membership of works councillors for a sample of firms which belong to employer associations. The latter data, spanning a longer time period, is summarised in Figure 1.

Figure 1: Union Density of Works Councillors and Heads of Works Councils 1965-2002

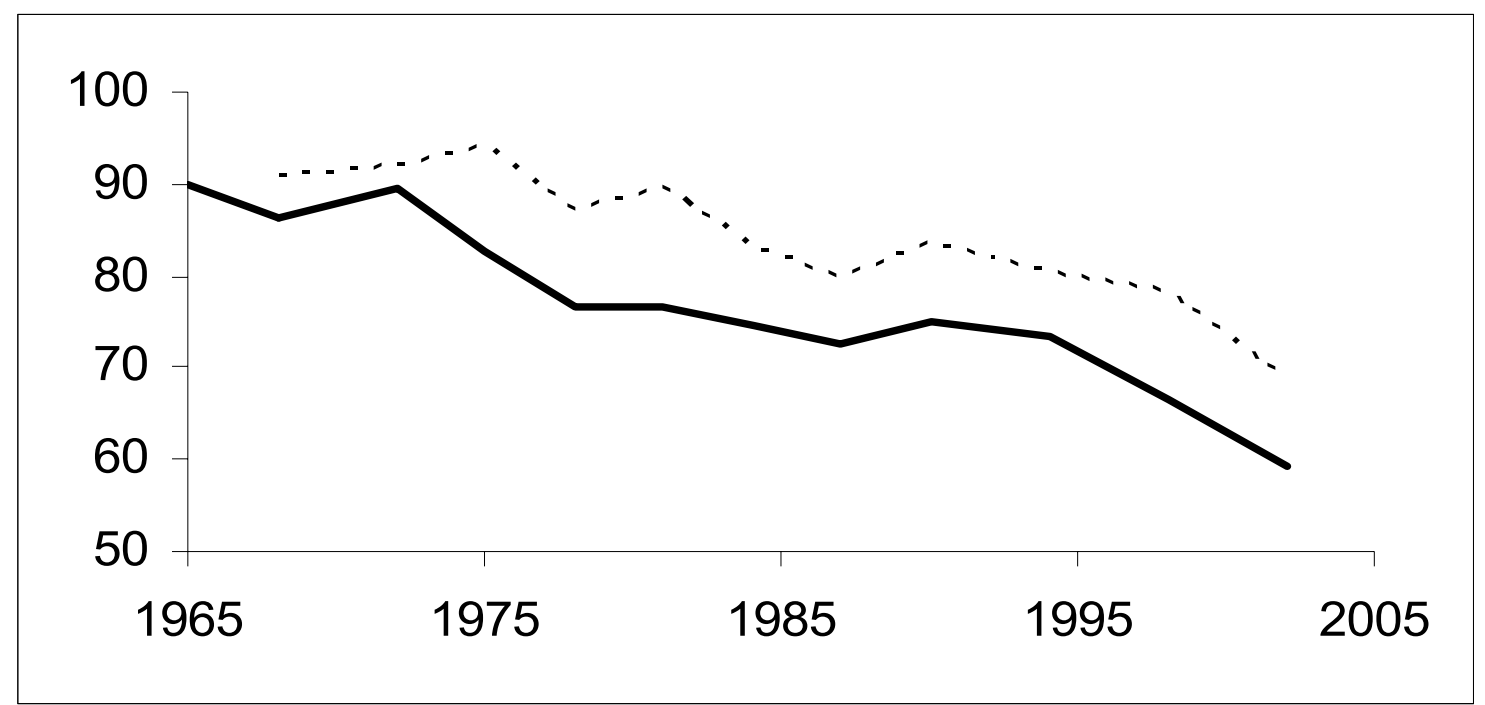

Sources: Niedenhoff (1981, 2003).

Figure 1 depicts the share of works councillors (bold line) and the heads of works councils (dotted line) belonging to a trade union. Works council elections have generally taken place every three years until 1990. Works councillors have been elected for a period of four years since then. Hence, the last election included in Figure 1 took place in 2002. The numbers summarised in Figure 1 indicate that the trade union density of works councillors has declined substantially from $90 \%$ in 1965 to about $75 \%$ in 1994 and to less than $60 \%$ in 2002 . The change in the fraction of union members among the heads of works councils has been comparable, although their density level has been considerably higher. 
The data from the German Trade Union Confederation show that the share of works councillors who are union members declined only marginally to slightly less than $80 \%$ in the period 1972 to 1994 (Hassel 1999a, 1999b). Until 1998, the next year in which works councils were elected, the respective share fell to about $73 \%$ (Behrens 2005). The differential results suggest that the union density of works councillors shrank (from 1972 - 1994) especially because the share of completely non-unionised works councils rose, which are not included into the data from the DGB. Irrespective of the source of information, trade union density among works councillors is found to be least in those industries in which the fraction of unionised employees is also relatively low (Niedenhoff 2003, Hassel 1999b).

Trade union density in Germany was relatively stable from the mid 60s to mid 70s and increased slightly during the second half of the 70s, only to fall again during the $1980 \mathrm{~s}$. Density jumped by about five $5 \%$ percentage points with German unification and has declined dramatically since then to - depending on the exact measure of union density looked at - approximately two-thirds or less of the level prevailing in the 1960s. This development is comparable to the change in the union density of works councillors as summarised in Figure 1, suggesting that the two types of density may be related. However, while the relative reduction in union densities among employees and works councillors from the mid 1960s to the beginning of this decade has been similar in magnitude, the development for the union density of works councillors has been less erratic.

Despite the various indications that the existence of works councils and the fraction of unionised works councillors may have a positive impact on the probability of an employee being a trade union member, immediate empirical evidence on this relationship is scarce. Schnabel and Wagner (2007) find that trade union presence at the workplace raises the probability of union membership in all 18 countries which are included into the analysis. This finding is consistent with evidence by Ebbinghaus and Visser (1999), Checchi and Visser (2005), Checchi and Lucifora (2002) and Visser (2002) for union density in Western European countries. Schnabel and Wagner (2006b) confirm the impact of union representation on membership for Germany. Estimating the probability of never being a union member, they obtain a significantly negative impact of union representation at the workplace.

All of the above mentioned studies do not measure the impact of works councils on trade union membership directly. There are only two studies - to our knowledge - which can provide evidence on this issue. Blaschke (2000) finds that the existence of statutory works councils in a country either has no impact on union density or actually reduces it in a sample 
of Western European nations. Thus, Blaschke's (2000) findings relate to legal conditions, rather than the actual situation. Estimating the probability of union membership, using individual data from 1976 to 1984 for Germany, Windolf and Haas (1989, p. 150) find that "the number of works councillors who are union members (average for the given industry)" has a positive effect on the probability of membership. They view their finding to be an indication of the recruiting effort of work councillors. ${ }^{6}$

Summing up, there are numerous theoretical arguments suggesting that the unionisation of works councils may positively influence an employee's decision whether to become a union member. While there are empirical indications that such a relationship exists, they are at best indirect, and an explicit test using recent representative data is lacking.

\section{Data and Empirical Specifications}

\subsection{Data}

Our data stems from the German Socio-Economic Panel (SOEP), a nationally representative longitudinal survey of the resident German population (Wagner et al. 1993, SOEP Group 2001). We use survey data for the years 2001 and 2003, because the survey includes information on union membership and on works councillorship in both years. Our sample consists of West German full- and part-time employees in the private and public sector with valid information on union membership and works councillorship. Observations from selfemployed persons and apprentices are excluded. ${ }^{8}$ We restrict ourselves to West German employees as there are too few observations for East Germany to calculate industry-specific shares of unionised works councillors in all cases. Sample weights are used in the descriptive as well as in the econometric analysis to take into account the sampling design of the different subsamples of the SOEP as well as panel attrition (Pannenberg et al. 2004).

\footnotetext{
${ }^{6}$ Windolf and Haas (1989, p. 155) furthermore interpret their results as showing "that union membership of works councillors has a positive effect on the union density of the firm. Simply speaking, if all works councillors in that firm are union members, the union density of the workforce in that firm is likely to be high (italics added)." Bearing in mind that they have no information on the existence of a works council in the particular firm, this interpretation seems to be rather bold.

${ }^{7}$ The data used in this paper was extracted using the Add-On package SOEP Menu written by Dr. John P. Haisken-DeNew (Haisken-DeNew 2005; http://www.soepmenu.de). J. Haisken DeNew and M. Hahn supplied SOEP Menu Plugins. Haisken-DeNew (2005) describes SOEP Menu in detail.

${ }^{8}$ Since we cannot identify employees with substantial decision rights ('Leitende Angestellte) in the data set precisely, we include them into our estimates. However, excluding the highest occupational category from the estimations, which implies excluding more than only 'Leitende Angestellte', does not change our subsequent findings. The results are available from the authors upon request.
} 
Information on individual union membership and works councillorship is generated from a survey question whether the respondent is a member of a trade union and/ or a works council respectively. In the survey year 2001, but not in 2003, additional information is available on the existence of a works council in the establishment of the respondent which we use to generate a corresponding dummy variable indicating the incidence of works councils (WCINC). A further key variable in our empirical analysis is the net union density of works councils. Since we do not have information on union membership of works councillors in a respondent's establishment, we utilise data on unionised works councils at the industry level. We calculate industry-specific net union densities of works councils (WCUD) as the share of unionised councillors among all works councillors in the particular industry. The industry dummies mimic the union structure in Germany, i.e. manufacturing, chemicals/ mining/energy, construction, transport, food/sundries/restaurants, education and science, and other public sector occupations (see Table A1 in the Appendix for documentation) and are generated from NACE 1-digit levels. ${ }^{9}$

\subsection{Empirical Specification}

Since we are interested in assessing the effects of works councils on trade union membership, we specify the following standard probit model:

$$
P\left(U_{i, t}=1 \mid X_{i, t}\right)=\Phi\left(\beta^{\prime} X_{i, t}\right),
$$

where $U_{i, t}=1$ if the individual is a union member, $X_{i, t}$ is the vector of covariates, $\beta$ is a vector of unknown parameters and $\Phi()$ is the cdf of the standard normal distribution.

One might argue that being a works councillor, i.e. the result of running for a works council and being elected, is endogenous with respect to the individual decision to join a union since, for example, unobservable individual abilities and/ or preferences have an impact on both outcomes. In this case, the estimated parameters of the single-equation probit model are biased. As a check of robustness, we additionally employ a recursive simultaneous twoequation probit model, which allows us to control for unobserved individual heterogeneity. Our specification builds on a reduced form latent variable specification of works councillorship $\left(W C_{i t}^{*}\right)$ and a structural form latent variable specification of union membership $\left(U_{i t}^{*}\right)$, where observed works councillorship $\left(W C_{i t}\right)$ enters the right-hand side:

\footnotetext{
${ }^{9}$ Note that there is a residual category for $W C U D$, resulting from cases in which information on industry status is missing. Industry-dummies are generated by SOEP-Menu-Plugin $p 2278$ (author: J. Haisken-DeNew).
} 


$$
\begin{array}{ll}
W C_{i t}^{*}= & \beta_{1}^{\prime} X_{1, i t}+\varepsilon_{1, i t} \\
U_{i t}^{*}=\alpha W C_{i t}+\beta_{2}^{\prime} X_{2, i t}+\varepsilon_{2, i t}
\end{array}
$$

The works councillorship variable $W C_{i t}$ will equal 1 if $W C_{i t}^{*}>0$. The union membership variable $U_{i, t}$ will equal 1 if $U_{i t}^{*}>0$, while $X_{1, i t}, X_{2, i t}$ are vectors of covariates and $\alpha, \beta_{1}^{\prime}, \beta_{2}^{\prime}$ are (vectors) of unknown parameters. The error terms $\varepsilon_{1, i t}, \varepsilon_{2, i t}$ are assumed to be independently and identically distributed as bivariate normal:

$$
\left(\begin{array}{l}
\varepsilon_{1, i t} \\
\varepsilon_{2, i t}
\end{array}\right) \sim \operatorname{IIDN}\left(\left[\begin{array}{l}
0 \\
0
\end{array}\right],\left[\begin{array}{ll}
1 & \rho \\
\rho & 1
\end{array}\right]\right)
$$

where $\rho$ is the correlation coefficient which can be interpreted as the correlation between unobservable explanatory variables of the two equations, such as unobserved individual abilities. Note that the identification of parameters in this specification hinges on the functional form chosen, since we have no variable at hand that influences the probability of being a works council but has no direct impact on the likelihood of being a union member. The parameters are estimated using maximum likelihood as the estimation criterion (Greene 1998, 2003). A Wald-Test of $\rho$ is used to test for endogeneity. ${ }^{10}$

We use two empirical specifications of models (1) and (2). Specification 1 makes use of SOEP-data for 2001 only, as information on the incidence of a works council in the establishment where the respondent works (WCINC) is available for this wave. In this case, $X_{i t}$ and $X_{2, i t}$ include our key variables $W C_{i t}$ (works councillorship of the respondent), WCINC (incidence of works council in establishment), WCUD (net union density of works councillors in industry) and an interaction of $W C U D$ and $W C I N C$. Specification 2 uses data for 2001 and 2003. In that case, $X_{i t}$ and $X_{2, i t}$ include $W C_{i t}, W C U D$ as well as an interaction of $W C U D$ and a dummy variable for the year 2003 (year 2003). The vectors $X_{i t}, X_{1, i t}, X_{2, i t}$ additionally contain the following joint subset of variables which have been found to determine union status: ${ }^{11}$ age, age squared, tenure, tenure squared and dummy variables for being a foreigner, being male, different firm size categories, doing an apprenticeship, having a university degree, having preferences for the social democratic party (SPD) or the Christian

\footnotetext{
${ }^{10}$ A likelihood-ratio-test comparing the likelihoods of the two independent single-equation probit models with the likelihood of the recursive simultaneous two-equation probit model yields identical results.

${ }^{11}$ See, for example, Windolf and Haas (1989), Wagner (1991), Lorenz and Wagner (1991), Fitzenberger et al. (1999), Goerke and Pannenberg (2004), Fitzenberger and Beck (2004), Schnabel and Wagner (2005, 2006a), and Fitzenberger et al. (2006)
} 
parties (CDU/CSU), whether the father was self-employed when the respondent was 15 years old, being a blue collar worker, the industry (NACE 1-digit) in which the respondent works and the state of residence ('Bundesland'). Table A.2 in the Appendix presents descriptive statistics for the variables used in the econometric analysis. For all specifications, estimated parameters, their robust “clustered" standard errors and marginal effects are reported.

\section{Results}

\subsection{Descriptive Evidence}

Table 1 presents the key findings of a descriptive analysis of union membership and works councillorship in West Germany.

\section{--- Table 1 ---}

The figures reveal that net union density, i.e. the share of employed union members among the number of all employees, in West Germany has still been declining since 2000 with levels of $21.2 \%$ in 2001 and $19.5 \%$ in 2003 . These numbers are in line with the result of a steadily waning net union density for the period 1985-2003 by Fitzenberger et al. (2006, Figure 2) and Schnabel and Wagner (2006a, Table 1). The net works councillor density, i.e. the ratio of the number of works councillors to the number of all employees, is constant over time with $4.3 \%$ in 2001 and $4.5 \%$ in 2003. Hence, the amendment of the Works Constitutions Act in 2001 which - among other alterations - increased the mandatory size of the works council, depending on firm size, had no obvious impact on the prevalence of works councillors in the short-term.

Our key variable, the net union density of works councillors, has declined remarkably between 2001 and 2003. In 2001, roughly 7 out of 10 works councillors were also union members, while in 2003 this applied only to 11 out of 20 works councillors. This indicates that the impact of unions on works councils is declining over time and mirrors the decline of the overall net union density. The information generated from the representative SOEP data for West Germany is consistent with the evidence provided by Niedenhoff (2003) on the basis of a non-representative sample for the whole of Germany. Niedenhoff (2003) also finds that the share of union members among works councillors has fallen substantially since the beginning of this decade (see also Figure 1).

Considering differences between the private and public sector, the net union density is remarkably higher in the public than in the private sector, while the erosion of union 
membership over time is observed in both sectors. Moreover, works councillors are more prevalent in the public than in the private sector. However, the share of unionised works councillors is much lower in the public sector than in the private sector. ${ }^{12}$ Within the private sector, the share of unionised works councillors is the highest in manufacturing and chemicals/ mining/ energy (see Table A.1 in the Appendix). The net union density of works councils has been decreasing by a striking $25 \%$ in the private sector between 2001 and 2003 while it has been relatively stable in the public sector. Hence, the erosion in the prevalence of unions in works councils is substantially more pronounced in the private than in the public sector. With respect to firm size, we observe that net union density as well as net works councillor density is increasing with firm size. Moreover, the decline in net union density is more distinct the larger the establishment is.

\subsection{Estimation Results}

Table 2 presents the results for the two single-equation probit specifications. ${ }^{13}$

\section{--- Table 2 ---}

Starting with specification 1 (columns 1 and 2) the parameter estimate for being a member of a works council is significantly positive. The estimated marginal effect indicates that being a works councillor increases the likelihood of being a union member by 32 percentage points. Hence, conditional on observable personal as well as firm characteristics we find a strong correlation between getting involved with co-determination issues as a works councillor and the probability of being a union member.

Trying to detect the effect of works council activities at the work place on union membership, we include the net union density of works councils (WCUD), the dummy variable for the incidence of a works council (WCINC) as well as an interaction of both variables. The existence of a works council (WCINC) has no significant impact on the probability of being a union member. At first sight, this finding may be surprising. However, it is in line with the evidence provided by Blaschke (2000) who detects no (or a significantly negative) impact of the existence of statutory works councils in a country on aggregate union density. Moreover,

\footnotetext{
${ }^{12}$ Keller and Schnell (2003) estimate the fraction of unionised works councillors in the public sector ('Personalräte') to be above $70 \%$ in 2002 . Since they base their calculation on a completely different data set than we use, the numbers are not directly comparable.

${ }^{13}$ Marginal effects are evaluated at the weighted sample means of all explanatory variables. Marginal effects for dummy variables are calculated as the discrete change of union membership the dummy variable changes from 0 to 1 .
} 
the estimated parameter of the interaction term is significantly positive, i.e. we observe a significantly positive effect of the average industry-specific net union density of works councillors if a works council exists in the particular establishment. Combining the marginal effect of the interaction term with the average of $\operatorname{WCUD}(66.76 \%)$ in 2001 , our estimate indicates that the likelihood of being a union member will increase by 20 percentage points if the works council in the firm exhibits the average share of unionised members among all works councillors instead of only consisting of non-union councillors. Compared to the estimated parameter for being a works councillor himself, the estimated effect is remarkably high. This indicates that unionised works councils, but not works councils as such, exert a substantial influence on an employee's decision to join a union. Our finding is consistent with viewing unionised works councils as (1) a recruitment agency of trade unions, (2) creating or emphasising a social custom of union membership, (3) being able to influence the personnel policy of companies, (4) providing employees with the experience of unionisation, and, finally, (5) being the institutional face of trade unions at the establishment level. It should be emphasised, though, that the positive interaction term of WCUD and WCINC does not allow the relative importance of the various channels of influence to be assessed.

Considering the parameter estimate of the dummy variable indicating whether the father was self-employed when the respondent was 15 years of age, we find a significantly negative impact on being a union member. Households in which the father was self-employed tend to oppose the union movement. We interpret the significantly negative effect of the 'father was self-employed' variable as evidence for social custom explanations of joining a union (see Goerke and Pannenberg 2004). With respect to individual characteristics of employees we observe a significantly positive effect of age, tenure, firm size and of being a blue collar worker on the probability of being unionised. Employees who prefer the Social Democrats exhibit a higher likelihood of being a union member. Yet, an employee with a university degree has a significantly lower probability of joining the union. All these results are in line with other empirical studies on the determinants of union membership in Germany (e.g. Fitzenberger and Beck 2004, Fitzenberger et al. 2006, Schnabel and Wagner 2006a, Goerke and Pannenberg 2004).

Specification 2 uses both waves of the SOEP in which information on works councillorship is available (Table 2, columns 3 and 4). This allows us to test whether the impact of the net union density of works councils on union membership has changed over time. Note however that we cannot control for the existence of a works council within the establishment of the 
respondent $(W C I N C)$ in this specification, since the relevant information is only available in 2001.

Works councillors exhibit a significantly higher probability of being a union member than non-councillors. The marginal effect is similar in size when compared to the result of specification 1. Moreover, the estimated parameter of the industry-specific average net union density of works councils is significantly positive. The estimated marginal effect implies that an employee of an establishment in a fictitious industry with the average share of unionised works councillors in both years, i.e. $62.1 \%$ (see table A.2 in the Appendix), exhibits a 12 percentage points higher chance of being a union member relative to a setting in which no councillors are members of a trade union. This indicates that the net union density is ceteris paribus higher in those industries in which unions exert a more intensive influence within works councils. The finding is again in line with an explanation that works councils are acting as recruitment agencies for unions, enhance a social custom of union membership, provide additional job security for union members or the experience good 'unionism', and behave as union representatives at the establishment level.

The estimated parameters of the dummy variable year 2003 as well as the interaction of WCUD and year 2003 are significant at the $10 \%$ level. The sum of the product of the estimated marginal effect for WCUD times the average value of $W C U D(62.1 \%)$, the marginal effect of year 2003 and the marginal effect of the interaction term times the average value of $W C U D$ in 2003 , i.e. $57.2 \%$, yields an overall marginal effect for $W C U D$ of $12.8 \%$. This number basically equals the previous one of $12.4 \%$ percentage points. Hence, we do not observe a decreasing impact of the net union density of works councils on the individual probability of being unionised in the course of time, conditional on observable attributes of the employees and their establishments.

With respect to most other explanatory variables of the probability of union membership, specification 2 yields similar results to the previous one. As an exception, the estimated parameter for individual preferences for Christian parties (CDU/CSU) has now become significantly negative, which is consistent with the fact that a major fraction of the CDU/CSU traditionally tends to oppose the political objectives of the German union movement.

One might object to the above interpretation of the estimation results that individual decisions to join a union as well as to run (successfully) for works council membership are determined jointly, e.g. unobservable individual characteristics and/ or preferences have an impact on both decisions. If this is so, the estimated parameters of the single-equation probit models will 
be biased. As a check of robustness, we estimated both empirical specifications of the recursive simultaneous two-equation probit model sketched above (equation 2). Table 3 presents the estimated parameters, their robust standard errors and the respective marginal effects of the union membership equation. ${ }^{14}$

\section{-- Table 3 ----}

Regarding the parameter estimates of the works council variables of specification 1, it is evident that the impact of being a member of the firm's works council exerts a significantly larger impact on the likelihood of being a union member when we model the joint probability of union membership and works councillorship. The marginal effect indicates that being a works councillor increases the probability of union membership by 72 percentage points. Moreover, the effect of the interaction of the existence of a works council in the particular firm $(W C I N C)$ and the industry-specific net union density of works councils (WCUD) is alleviated, while still being significantly positive. The marginal effect indicates that the probability of being unionised will increase by roughly 13 percentage points if the share of unionised members among all works councillors of the particular firm rises from zero to the average share. Hence, controlling for the simultaneity of being a union member and a member of the works council, we again find supportive evidence that works councils do indeed have a positive impact on an employee's decision of being a union member. As regards the other parameter estimates, we obtain similar results to the single-equation probits. The estimated correlation parameter is significantly negative. This indicates the necessity to estimate a simultaneous two-equation model though identification in our particular empirical specification hinges on the functional form chosen.

The estimates of specification 2 of the recursive simultaneous two-equation probit model support the previous results. The estimated parameter for being a works councillor is significantly positive and indicates that the likelihood of being a union member will increase by 72 percentage points if the employee is a works council member. Moreover, the estimated marginal effect of the significantly positive point estimate of $W C U D$ shows that an employee in a fictitious industry with the average net union density of works councils has a 6 percentage points higher probability of being unionised, compared to the non-union case. If we additionally take into account the two estimated marginal effects of year 2003 and of the interaction of WCUD and year 2003, we again find the same result as if we just take into

\footnotetext{
${ }^{14}$ The parameter estimates of the reduced form works councillorship equation are not of primary interest for our particular analysis. Results for specification 1, that is, for 2001, are found in the Appendix in Table A.3. Further results are available from the authors on request.
} 
account the marginal effect of $W C U D$. The estimated correlation parameter is significantly negative and the respective Wald-Test (Wald-Test_ $\rho$ ) indicates that there is indeed a significant correlation between unobserved factors in both equations. All the other parameter estimates as well as the test statistic of the overall Wald-test (Wald-Test_X) are very similar to those of specification 1 .

\section{Conclusions}

Union membership in Germany has declined remarkably since the 1990s. Contemporaneously, the share of works councillors who are union members has fallen. In 2003, only every fifth employee in (West) Germany still belonged to a trade union while less than 6 out of 10 works councillors were trade union members. Our empirical findings suggest that the decline in the unionisation of works councillors and the fall of the overall union density in West Germany are closely linked. In particular, our results indicate that it is not the mere existence of a works council in the firm, but the proximity of works councils to trade unions, as measured by the fraction of works councillors in an industry who are trade union members themselves, that represents an important determinant of trade union membership by ordinary employees. To illustrate the magnitude of this impact, assume an average employee who is working in an establishment with a works council in a fictitious industry with an average share of unionised works councillors. Our findings imply that if the average share of unionised works councillors in this industry declines by $10 \%$, the probability of this employee being a member of a trade union will also fall by $10 \%$. Hence, our results provide one important explanation for the stylised fact that changes in the composition of the work force have only played a minor role for the fall in union density in Germany (Fitzenberger et al. 2006, Schnabel and Wagner 2006a).

Our results strongly rely on the (change in the) net union density of works councillors within an industry. Ideally, one would also like to know how much the probability of union membership of an employee will change by if the fraction of works councillors within the establishment varies in which the respective employee works. This information could help, for example, to evaluate the gains from organising campaigns by trade unions. Unfortunately, the Socio-Economic Panel (SOEP) does not provide the relevant information. Moreover, our data does not allow us to determine whether the positive impact of unionised works councils on union membership is due to (1) their recruitment efforts, (2) them enforcing a norm or social custom more actively, (3) influencing personnel policy, (4) providing employees with 
the experience of unionism, or (5) being the institutional face of trade unions at the establishment level. Hence, future research on these topics is necessary. 


\section{References}

Addison, John T. (1999), Nonunion Representation in Germany, Journal of Labor Research, Vol. 20 (1), 73-91.

Addison, John T., Bellmann, Lutz, Schnabel, Claus and Joachim Wagner (2004), The Reform of the German Works Constitution Act: A Critical Assessment, Industrial Relations, Vol. 43 (2), 392-420.

Addison, John T., Schnabel, Claus and Joachim Wagner (2000), Nonunion representation in Germany, 365-385, in: Kaufman, Bruce and Daphne G. Taras (eds), Nonunion Employee Representation: History, Contemporary Practice, and Policy, M.E. Sharpe: Armonk, NY.

Akerlof, George A. (1980), A Theory of Social Custom, of which Unemployment may be One Consequence, The Quarterly Journal of Economics, Vol. 94, 749-775.

Behrens, Martin (2005), Die Rolle der Betriebsräte bei der Werbung von Gewerkschaftsmitgliedern, WSI Mitteilungen, Vol. 58, 329-338.

Blaschke, Sabine (2000), Union Density and European Integration: Diverging Convergence, European Journal of Industrial Relations, Vol. 6 (2), 217-236.

Booth, Alison L. and Monojit Chatterji (1993), Reputation, Membership and Wages in an Open Shop Trade Union, Oxford Economic Papers, Vol. 45, 23-41.

Booth, Alison L. and Monojit Chatterji (1995), Union Membership and Wage Bargaining When Membership is Not Compulsory, The Economic Journal, Vol. 105, 345-360.

Böckerman, Petri and Roope Uusitalo (2006), Erosion of the Ghent System and Union Membership Decline: Lessons from Finland, British Journal of Industrial Relations, Vol. 44 (2), 283-303.

Bryson, Alex and Rafael Gomez (2003), Buying into Membership, 72-91, in: Gospel, Howard and Stephen Wood (eds), Representing Workers: Trade Union Recognition and Membership in Britain, Routledge: London.

Checchi, Daniele and Claudio Lucifora (2002), Unions and Labour Market Institutions in Europe, Economic Policy, Vol. 35, 361-408.

Checchi, Daniele and Jelle Visser (2005), Pattern Persistence in European Trade Union Density - A Longitudinal Analysis 1950-1996, European Sociological Review, Vol. 21 (1), 1-21.

Corneo, Giacomo (1993), Semi-unionized Bargaining with Endogenous Membership and Management Opposition, Journal of Economics, Vol. 57, 169-188.

Corneo, Giacomo (1995), Social Custom, Management Opposition, and Trade Union Membership, European Economic Review, Vol. 39, 275-292.

Corneo, Giacomo (1997), The Theory of the Open-Shop Trade Union Reconsidered, Labour Economics, Vol. 4, 71-84.

Ebbinghaus, Bernhard and Jelle Visser (1999), When Institutions Matter - Union Growth and Decline in Western Europe, 1950-1995, European Sociological Review, Vol. 15 (2), 135158.

Fitzenberger, Bernd and Martin Beck (2004), Changes in Union Membership Over Time: A Panel Analysis for Germany, Labour, Vol. 18 (3), 329-362.

Fitzenberger, Bernd, Haggeney, Isabelle and Michaela Ernst (1999), Wer ist noch Mitglied in Gewerkschaften?, Eine Panelanalyse für Westdeutschland, Zeitschrift für Wirtschaftsund Sozialwissenschaften, Vol. 119 (2), 223-264. 
Fitzenberger, Bernd, Kohn, Karsten and Qingwei Wang (2006), The Erosion of Union Membership in Germany: Determinants, Densities, Decompositions, IZA Discussion Paper 2193.

Goerke, Laszlo (1997), An Open Shop, Wage Bargaining, and Taxation - A Note, Oxford Economic Papers, Vol. 49, 651-657.

Goerke, Laszlo and Markus Pannenberg (2004), Norm-Based Trade Union Membership: Evidence for Germany, German Economic Review, Vol. 5 (4), 481-504.

Greene, William H. (1998), Gender Economics Courses in Liberal Arts Colleges: Further Results, Journal of Economic Education, Vol. 29 (4), 291-300.

Greene, William H. (2003), Econometric Analysis, 5th ed., Prentice Hall: London.

Haisken-DeNew, John P. (2005), SOEP Menu: A Menu-Driven Stata/SE Interface for Accessing the German Socio-Economic Panel, http://www.soepmenu.de.

Hassel, Anke (1999a), Gewerkschaften und sozialer Wandel, Nomos Verlagsgesellschaft: Baden-Baden.

Hassel, Anke (1999b), The Erosion of the German System of Industrial Relations, British Journal of Industrial Relations, Vol. 37 (3), 483-505.

Heery, Edmund (2003), Gewerkschaftliche Strategien gegen den Mitgliederschwund, WSI Mitteilungen, Vol. 56, 522-527.

Holmlund, Bertil and Per Lundborg (1999), Wage Bargaining, Union Membership, and the Organization of Unemployment Insurance, Labour Economics, Vol. 6, 397-415.

Jones, Stephen R. G. and C. J. McKenna (1994), A Dynamic Model of Union Membership and Employment, Economica. Vol. 61, 179-189.

Keller, Berndt and Rainer Schnell (2003), Zur empirischen Analyse von Personalräten Strukturdaten und Probleme, WSI Mitteilungen, Vol. 56, 185-193.

Kotthoff, Hermann (1979), Zum Verhältnis von Betriebsrat und Gewerkschaft. Ergebnisse einer empirischen Untersuchung, 298-325, in: Joachim Bergmann (ed), Beiträge zur Soziologie der Gewerkschaften, Suhrkamp: Frankfurt am Main.

Lorenz, Wilhelm and Joachim Wagner (1991), Bestimmungsgründe von Gewerkschaftsmitgliedschaft und Organisationsgrad, Zeitschrift für Wirtschafts- und Sozialwissenschaften, Vol. 111, 65-82.

Moreton, David R. (1998), An Open Trade Union Model of Wages, Effort and Membership, European Journal of Political Economy, Vol. 14, 511-527.

Moreton, David R. (1999), A Model of Labour Productivity and Union Density in British Private Sector Unionised Establishments, Oxford Economic Papers, Vol. 51, 322-344.

Müller-Jentsch, Walther (1995), Germany: From Collective Voice to Co-management, 53-78, in: Rogers, Joel and Wolfgang Streeck (eds.), Works Councils - Consultation, Representation and Cooperation in Industrial Relations, The University of Chicago Press: Chicago and London.

Naylor, Robin and Martin Cripps (1993), An Economic Theory of the Open Shop Trade Union, European Economic Review, Vol. 37, 1599-1620.

Naylor, Robin and Oddbjörn Raaum (1993), The Open Shop Union, Wages and Management Opposition, Oxford Economic Papers, Vol. 45, 589-604.

Niedenhoff, Horst-Udo (1981), Die Betriebsratswahlen von 1952 - 1978: Eine vergleichende Untersuchung ihrer innerbetrieblichen Abläufe und Ergebnisse, Köln.

Niedenhoff, Horst-Udo (2003), Betriebsratswahlen 2002, IW Köln.

Pannenberg, Markus et al. (2004), Sampling and Weighting, in: Haisken-DeNew, John and Bernd Frick (eds), Desktop Companion to the GSOEP, Berlin. 
Schnabel, Claus (2003), Determinants of Trade Union Membership, 13-43, in: Addison, John T. and Claus Schnabel (eds), International Handbook of Trade Unions, Edward Elgar: Cheltenham, UK and Northampton, MA, USA.

Schnabel, Claus and Joachim Wagner (2005), Determinants of Trade Union Membership in Western Germany: Evidence from Micro Data, 1980-2000, Socio-Economic Review, Vol. $3,1-24$.

Schnabel, Claus and Joachim Wagner (2006a), The Persistent Decline in Unionization in Western and Eastern Germany, 1980-2004: What Can We Learn from a Decomposition Analysis?, IZA Discussion Paper 2388.

Schnabel, Claus and Joachim Wagner, J. (2006b), Who Are the Workers Who Never Joined a Union? Empirical Evidence from Western and Eastern Germany, Industrielle Beziehungen, Vol. 13 (2), 118-131.

Schnabel, Claus and Joachim Wagner (2007), Union Density and Determinants of Union Membership in 18 EU Countries: Evidence from Micro Data, 2002/03, Industrial Relations Journal, Vol. 38(1), 5-32.

SOEP Group (2001). The German Socio-Economic Panel After More Than 15 Years Overview, Vierteljahrshefte zur Wirtschaftsforschung, Vol. 70, 7-14.

Streeck, Wolfgang (1981), Gewerkschaftliche Organisationsprobleme in der sozialstaatlichen Demokratie, Athenäum: Königstein (Taunus).

Visser, Jelle (2002), Why Fewer Workers Join Unions in Europe: A Social Custom Explanation of Membership Trends, British Journal of Industrial Relations, Vol. 40 (3), 403-430.

Wagner, Gerd, Burkhauser, Richard and Friederike Behringer (1993). The English Language Public Use File of the German Socio-Economic Panel, The Journal of Human Resources, Vol. 28, 429-433.

Wagner, Joachim (1991), Gewerkschaftsmitgliedschaft und Arbeitseinkommen in der Bundesrepublik Deutschland, IFO-Studien, Vol. 37 (2), 109-140.

Western, Bruce (1993), Postwar Unionization in Eighteen Advanced Capitalist Countries, American Sociological Review, Vol. 58, 266-282.

Western, Bruce (1997), Between Class and Market - Postwar Unionization in the Capitalist Democracies, Princeton University Press: Princeton, NJ.

Windolf, Paul and Joachim Haas (1989), Who Joins the Union?, Determinants of Trade Union Membership in Germany, European Sociological Review, Vol. 5, 147-166. 
Table 1: Union Membership and Works Councillorship in West Germany

\begin{tabular}{lcccccc}
\hline & \multicolumn{2}{c}{2001} & & \multicolumn{2}{c}{2003} \\
& $\begin{array}{l}\text { Net } \\
\text { Union } \\
\text { Density }\end{array}$ & $\begin{array}{l}\text { Net Works } \\
\text { Councillors } \\
\text { Density }\end{array}$ & $\begin{array}{l}\text { Net Union } \\
\text { Density of } \\
\text { Works } \\
\text { Councils }\end{array}$ & $\begin{array}{l}\text { Net } \\
\text { Union } \\
\text { Density }\end{array}$ & $\begin{array}{l}\text { Net Works } \\
\text { Councillors } \\
\text { Density }\end{array}$ & $\begin{array}{l}\text { Net Union } \\
\text { Density of } \\
\text { Works } \\
\text { Councils }\end{array}$ \\
\hline All & 21.2 & 4.3 & 68.7 & 19.5 & 4.5 & 55.6 \\
\hline Public Sector & 26.6 & 5.9 & 56.8 & 24.7 & 6.9 & 54.6 \\
Private Sector & 19.3 & 3.8 & 75.5 & 17.5 & 3.6 & 56.3 \\
\hline Firm Size & & & & & & \\
$\mathrm{X}<20$ employees & 10.2 & 1.3 & $/$ & 10.2 & 2.5 & $/$ \\
$20 \leq \mathrm{X}<200$ empl. & 17.0 & 5.1 & 53.7 & 16.2 & 5.2 & 49.9 \\
$200 \leq \mathrm{X}<2000$ empl. & 24.3 & 5.3 & 75.4 & 23.1 & 5.9 & 59.1 \\
$\mathrm{X} \geq 2000$ employees & 35.1 & 5.8 & 76.8 & 30.4 & 4.7 & 63.7 \\
\hline N. of observations & \multicolumn{7}{c}{7623} & & 6807 & \\
\hline
\end{tabular}

Source: SOEP 2001, 2003. Survey weights used.

/: less than 20 unionised works councillors in that particular group. 
Table 2: Determinants of Union Membership in West Germany

\begin{tabular}{|c|c|c|c|c|}
\hline & \multicolumn{2}{|c|}{ Specification 1 (2001) } & \multicolumn{2}{|c|}{ Specification $2(2001 / 03)$} \\
\hline & $\begin{array}{c}\text { Parameter / } \\
\text { Std.-Err. }\end{array}$ & $\begin{array}{c}\text { Marginal } \\
\text { Effect }\end{array}$ & $\begin{array}{c}\text { Parameter / } \\
\text { Std.-Err. }\end{array}$ & $\begin{array}{c}\text { Marginal } \\
\text { Effect }\end{array}$ \\
\hline Member of works council $(W C)$ & $\begin{array}{l}0.981^{* *} \\
(0.100)\end{array}$ & 0.324 & $\begin{array}{l}1.051^{* *} \\
(0.090)\end{array}$ & 0.352 \\
\hline Net union density of works councils (WCUD) & $\begin{array}{l}-0.004 \\
(0.006)\end{array}$ & $\begin{array}{r}-0.001 \\
--\end{array}$ & $\begin{array}{l}0.006^{*} \\
(0.003)\end{array}$ & 0.002 \\
\hline Incidence works council in firm (WCINC) & $\begin{array}{l}-0.122 \\
(0.371)\end{array}$ & $\begin{array}{r}-0.030 \\
--\end{array}$ & -- & -- \\
\hline Interaction of $W C U D$ with $W C I N C$ & $\begin{array}{l}0.011^{*} \\
(0.006)\end{array}$ & 0.003 & -- & $\begin{array}{l}-- \\
--\end{array}$ \\
\hline Interaction $W C U D$ with dummy year 2003 & -- & $\begin{array}{l}-- \\
--\end{array}$ & $\begin{array}{l}-0.004+ \\
(0.002)\end{array}$ & $\begin{array}{r}-0.001 \\
--\end{array}$ \\
\hline Dummy variable: year 2003 & $\begin{array}{l}-- \\
--\end{array}$ & $\begin{array}{l}-- \\
--\end{array}$ & $\begin{array}{l}0.258+ \\
(0.152)\end{array}$ & $\begin{array}{r}0.062 \\
--\end{array}$ \\
\hline Male & $\begin{array}{l}0.192 * * \\
(0.064)\end{array}$ & $\begin{array}{r}0.045 \\
--\end{array}$ & $\begin{array}{l}0.173 * * \\
(0.057)\end{array}$ & 0.041 \\
\hline Foreigner & $\begin{array}{l}-0.139 \\
(0.093)\end{array}$ & $\begin{array}{r}-0.031 \\
--\end{array}$ & $\begin{array}{l}-0.022 \\
(0.080)\end{array}$ & $\begin{array}{r}-0.005 \\
--\end{array}$ \\
\hline Part-time employment & $\begin{array}{l}-0.158+ \\
(0.083)\end{array}$ & $\begin{array}{r}-0.036 \\
--\end{array}$ & $\begin{array}{l}-0.115+ \\
(0.069)\end{array}$ & $\begin{array}{r}-0.027 \\
--\end{array}$ \\
\hline Age (in years) & $\begin{array}{l}0.066^{* *} \\
(0.020)\end{array}$ & 0.016 & $\begin{array}{l}0.064 * * \\
(0.018)\end{array}$ & $\begin{array}{r}0.015 \\
--\end{array}$ \\
\hline Age squared (in years) & $\begin{array}{l}-0.001 * * \\
(0.000)\end{array}$ & $\begin{array}{r}-0.000 \\
--\end{array}$ & $\begin{array}{l}-0.001 * * \\
(0.000)\end{array}$ & $\begin{array}{r}-0.000 \\
--\end{array}$ \\
\hline Tenure (in years) & $\begin{array}{l}0.033^{* * *} \\
(0.009)\end{array}$ & $\begin{array}{r}0.008 \\
--\end{array}$ & $\begin{array}{l}0.042 * * \\
(0.008)\end{array}$ & $\begin{array}{r}0.010 \\
--\end{array}$ \\
\hline Tenure squared (in years) & $\begin{array}{l}-0.000+ \\
(0.000)\end{array}$ & $\begin{array}{r}-0.000 \\
--\end{array}$ & $\begin{array}{l}-0.001 * \\
(0.000)\end{array}$ & $\begin{array}{r}-0.000 \\
--\end{array}$ \\
\hline Apprenticeship & $\begin{array}{l}0.056 \\
(0.088)\end{array}$ & 0.013 & $\begin{array}{l}0.042 \\
(0.078)\end{array}$ & 0.010 \\
\hline University degree & $\begin{array}{l}-0.232 * \\
(0.106)\end{array}$ & $\begin{array}{r}-0.052 \\
--\end{array}$ & $\begin{array}{l}-0.240^{*} \\
(0.093)\end{array}$ & $\begin{array}{r}-0.053 \\
--\end{array}$ \\
\hline Prefers Social Democrats $(S P D)$ & $\begin{array}{l}0.374 * * \\
(0.062)\end{array}$ & 0.098 & $\begin{array}{l}0.355 * * \\
(0.054)\end{array}$ & $\begin{array}{r}0.093 \\
--\end{array}$ \\
\hline Prefers Christian Parties (CDU/CSU) & $\begin{array}{l}-0.106 \\
(0.071)\end{array}$ & -0.024 & $\begin{array}{l}-0.117 * \\
(0.055)\end{array}$ & $\begin{array}{r}-0.027 \\
--\end{array}$ \\
\hline Blue collar worker & $\begin{array}{l}0.512 * * \\
(0.066)\end{array}$ & $\begin{array}{r}0.133 \\
--\end{array}$ & $\begin{array}{l}0.466 * * \\
(0.053)\end{array}$ & 0.121 \\
\hline Father was self-employed & $\begin{array}{l}-0.157+ \\
(0.087)\end{array}$ & $\begin{array}{r}-0.035 \\
--\end{array}$ & $\begin{array}{l}-0.130+ \\
(0.077)\end{array}$ & $\begin{array}{r}-0.029 \\
--\end{array}$ \\
\hline Firm size: $20 \leq X<200$ employees & $\begin{array}{l}0.081 \\
(0.096)\end{array}$ & 0.020 & $\begin{array}{l}0.326 * * \\
(0.072)\end{array}$ & $\begin{array}{r}0.083 \\
--\end{array}$ \\
\hline Firm size: $200 \leq X<2000$ employees & $\begin{array}{l}0.183+ \\
(0.107)\end{array}$ & 0.046 & $\begin{array}{l}0.571 * * \\
(0.075)\end{array}$ & $\begin{array}{r}0.156 \\
--\end{array}$ \\
\hline Firm size: $X \geq 200$ employees & $\begin{array}{l}0.427 * * \\
(0.105)\end{array}$ & 0.112 & $\begin{array}{l}0.792 * * \\
(0.073)\end{array}$ & $\begin{array}{r}0.223 \\
--\end{array}$ \\
\hline Constant & $\begin{array}{l}-3.147 * * \\
(0.582)\end{array}$ & -- & $\begin{array}{l}-3.716^{* *} \\
(0.453)\end{array}$ & -- \\
\hline $\begin{array}{l}\text { Industry dummies (NACE } 1 \text { - digit) } \\
\text { State dummies }\end{array}$ & & & & \\
\hline $\begin{array}{l}\text { Number of Observations } \\
\text { Wald X (degrees of freedom) }\end{array}$ & 892.2 & $42) * *$ & $\begin{array}{r}13 \\
956.0\end{array}$ & $42)^{* *}$ \\
\hline
\end{tabular}

Source: GSOEP 2001, 2003. Sample weights are used. Robust standard errors are in parentheses. Significance levels: ** $(0.01), *(0.05),+(0.1)$. Wald_X: Wald - Test with $\mathrm{H}_{0}$ : no joint significance of all regressors. 
Table 3: Check of Robustness: Simultaneous Equation Model of the Determinants of Union Membership in West Germany

\begin{tabular}{|c|c|c|c|c|}
\hline & \multicolumn{2}{|c|}{ Specification 1 (2001) } & \multicolumn{2}{|c|}{ Specification $2(2001 / 03)$} \\
\hline & $\begin{array}{l}\text { Parameter / } \\
\text { Std.-Err. }\end{array}$ & $\begin{array}{c}\text { Marginal } \\
\text { Effect }\end{array}$ & $\begin{array}{c}\text { Parameter / } \\
\text { Std.-Err. }\end{array}$ & $\begin{array}{c}\text { Marginal } \\
\text { Effect }\end{array}$ \\
\hline Member of works council $(W C)$ & $\begin{array}{l}2.166^{* * *} \\
(0.259)\end{array}$ & 0.721 & $\begin{array}{l}2.148 * * \\
(0.357)\end{array}$ & $\begin{array}{r}0.717 \\
\end{array}$ \\
\hline Net union density of works councils (WCUD) & $\begin{array}{l}-0.004 \\
(0.005)\end{array}$ & $\begin{array}{r}-0.001 \\
--\end{array}$ & $\begin{array}{l}0.006^{*} \\
(0.003)\end{array}$ & $\begin{array}{r}0.001 \\
\end{array}$ \\
\hline Incidence works council in firm (WCINC) & $\begin{array}{l}-0.076 \\
(0.367)\end{array}$ & $\begin{array}{r}-0.019 \\
--\end{array}$ & -- & $\begin{array}{l}-- \\
--\end{array}$ \\
\hline Interaction of $W C U D$ with $W C I N C$ & $\begin{array}{l}0.010+ \\
(0.005)\end{array}$ & $\begin{array}{r}0.002 \\
--\end{array}$ & $\begin{array}{l}-- \\
--\end{array}$ & $\begin{array}{l}-- \\
--\end{array}$ \\
\hline Interaction $W C U D$ with dummy year 2003 & -- & $\begin{array}{l}-- \\
--\end{array}$ & $\begin{array}{l}-0.004+ \\
(0.002)\end{array}$ & $\begin{array}{r}-0.001 \\
--\end{array}$ \\
\hline Dummy variable: year 2003 & $\begin{array}{l}-- \\
--\end{array}$ & $\begin{array}{l}-- \\
--\end{array}$ & $0.248+$ & $\begin{array}{r}0.061 \\
\end{array}$ \\
\hline Male & $\begin{array}{l}0.181 * * \\
(0.063)\end{array}$ & $\begin{array}{r}0.044 \\
--\end{array}$ & $\begin{array}{l}0.165 * * \\
(0.055)\end{array}$ & $\begin{array}{r}0.040 \\
--\end{array}$ \\
\hline Foreigner & $\begin{array}{l}-0.177^{*} \\
(0.090)\end{array}$ & $\begin{array}{r}-0.040 \\
--\end{array}$ & $\begin{array}{l}-0.042 \\
(0.076)\end{array}$ & $\begin{array}{r}-0.010 \\
--\end{array}$ \\
\hline Part-time employment & $\begin{array}{l}-0.137 \\
(0.081)\end{array}$ & $\begin{array}{r}-0.032 \\
--\end{array}$ & $\begin{array}{l}-0.097 \\
(0.068)\end{array}$ & $\begin{array}{r}-0.023 \\
--\end{array}$ \\
\hline Age (in years) & $\begin{array}{l}0.057 * * \\
(0.019)\end{array}$ & $\begin{array}{r}0.014 \\
--\end{array}$ & $\begin{array}{l}0.058 * * \\
(0.018)\end{array}$ & $\begin{array}{r}0.014 \\
--\end{array}$ \\
\hline Age squared (in years) & $\begin{array}{l}-0.001 * * \\
(0.000)\end{array}$ & $\begin{array}{r}-0.000 \\
--\end{array}$ & $\begin{array}{l}-0.001 * * \\
(0.000)\end{array}$ & $\begin{array}{r}-0.000 \\
--\end{array}$ \\
\hline Tenure (in years) & $\begin{array}{l}0.032 * * \\
(0.009)\end{array}$ & $\begin{array}{r}0.008 \\
--\end{array}$ & $\begin{array}{l}0.040 * * \\
(0.008)\end{array}$ & $\begin{array}{r}0.010 \\
--\end{array}$ \\
\hline Tenure squared (in years) & $\begin{array}{l}-0.001^{*} \\
(0.000)\end{array}$ & $\begin{array}{r}-0.000 \\
--\end{array}$ & $\begin{array}{l}-0.001 * \\
(0.000)\end{array}$ & $\begin{array}{r}-0.000 \\
--\end{array}$ \\
\hline Apprenticeship & $\begin{array}{l}0.027 \\
(0.086)\end{array}$ & $\begin{array}{r}0.007 \\
--\end{array}$ & $\begin{array}{l}0.018 \\
(0.077)\end{array}$ & $\begin{array}{r}0.004 \\
--\end{array}$ \\
\hline University degree & $\begin{array}{l}-0.238^{*} \\
(0.104)\end{array}$ & $\begin{array}{r}-0.054 \\
--\end{array}$ & $\begin{array}{l}-0.242 * * \\
(0.092)\end{array}$ & $\begin{array}{r}-0.055 \\
--\end{array}$ \\
\hline Prefers Social Democrats $(S P D)$ & $\begin{array}{l}0.352^{* *} \\
(0.061)\end{array}$ & $\begin{array}{r}0.093 \\
--\end{array}$ & $\begin{array}{l}0.341 * * \\
(0.053)\end{array}$ & $\begin{array}{r}0.091 \\
\end{array}$ \\
\hline Prefers Christian Parties $(C D U / C S U)$ & $\begin{array}{l}-0.090 \\
(0.070)\end{array}$ & $\begin{array}{r}-0.021 \\
--\end{array}$ & $\begin{array}{l}-0.111^{*} \\
(0.055)\end{array}$ & $\begin{array}{r}-0.026 \\
--\end{array}$ \\
\hline Blue collar worker & $\begin{array}{l}0.487 * * \\
(0.065)\end{array}$ & $\begin{array}{r}0.129 \\
\\
\end{array}$ & $\begin{array}{l}0.451 * * \\
(0.052)\end{array}$ & $\begin{array}{r}0.119 \\
\\
--\end{array}$ \\
\hline Father was self-employed & $\begin{array}{l}-0.165^{*} \\
(0.083)\end{array}$ & $\begin{array}{r}-0.038 \\
--\end{array}$ & $\begin{array}{l}-0.138+ \\
(0.073)\end{array}$ & $\begin{array}{r}-0.032 \\
--\end{array}$ \\
\hline Firm size: $20 \leq X<200$ employees & $\begin{array}{l}0.034 \\
(0.094)\end{array}$ & $\begin{array}{r}0.008 \\
--\end{array}$ & $\begin{array}{l}0.285^{* *} \\
(0.071)\end{array}$ & $\begin{array}{r}0.074 \\
--\end{array}$ \\
\hline Firm size: $200 \leq X<2000$ employees & $\begin{array}{l}0.133 \\
(0.105)\end{array}$ & $\begin{array}{r}0.034 \\
--\end{array}$ & $\begin{array}{l}0.527 * * \\
(0.074)\end{array}$ & $\begin{array}{r}0.145 \\
--\end{array}$ \\
\hline Firm size: $X \geq 200$ employees & $\begin{array}{l}0.376^{* *} \\
(0.104)\end{array}$ & $\begin{array}{r}0.100 \\
--\end{array}$ & $\begin{array}{l}0.749 * * \\
(0.073)\end{array}$ & $\begin{array}{r}0.213 \\
\\
\end{array}$ \\
\hline Constant & $\begin{array}{l}-2.888 * * \\
(0.570)\end{array}$ & $\begin{array}{l}-- \\
--\end{array}$ & $\begin{array}{l}-3.484 * * \\
(0.445)\end{array}$ & $\begin{array}{l}-- \\
--\end{array}$ \\
\hline Correlation par. $\left(0.5^{*} \ln [(1+\rho) /(1-\rho)]\right.$ & $\begin{array}{l}-0.701 * * \\
(0.204)\end{array}$ & $\begin{array}{l}-- \\
-- \\
\end{array}$ & $\begin{array}{l}-0.613^{*} \\
(0.243) \\
\end{array}$ & $\begin{array}{l}-- \\
-- \\
\end{array}$ \\
\hline $\begin{array}{l}\text { Industry dummies (NACE 1- digit) } \\
\text { State dummies }\end{array}$ & & & & \\
\hline Number of Observations & & & & \\
\hline Wald-Test_X (degrees of freedom) & 1562 & $(80)^{* *}$ & 1406 & $(80)^{* *}$ \\
\hline Wald-Test_ $\rho$ (degrees of freedom) & & & & $(1)^{*}$ \\
\hline
\end{tabular}

Source: GSOEP 2001, 2003. Sample weights are used. Robust standard errors are in parentheses. Significance levels: $* *(0.01), *(0.05),+(0.1)$. Wald_Test_X: $\mathrm{H}_{0}:$ no joint significance of all regressors. Wald-Test_ $\rho: \mathrm{H}_{0}: \rho=0$. Estimated parameters of the works council equation for 2001 are documented in Table A.3 in the Appendix. 


\section{Appendix}

Table A.1: Industry-specific Net Union Density of Works Councils (WCUD)

\begin{tabular}{lll}
\hline & & WCUD \\
\hline & 2001 & 2003 \\
\hline Manufacturing & 78.91 & 72.21 \\
Chemicals/ Mining/ Energy & 73.14 & 79.36 \\
Construction & 73.15 & 63.96 \\
Transport & 89.76 & 73.32 \\
Food/ Sundries/ Restaurants & 44.69 & 35.26 \\
Education and Science & 49.69 & 57.75 \\
Other Public Sector & 59.06 & 48.45 \\
Industry info missing & 83.52 & 56.49 \\
\hline N. of observations & 7623 & 6807
\end{tabular}

Source: SOEP 2001, 2003. Survey weights are used. N=14430. 
Table A.2: Descriptive Statistics

\begin{tabular}{|c|c|c|}
\hline Variable & Mean & Std. Dev. \\
\hline Union membership $(U)$ & 0.20 & 0.40 \\
\hline Works councillorship (WC) & 0.04 & 0.21 \\
\hline Net union density of works councils ( $W C U D$ ) & 62.07 & 12.74 \\
\hline Incidence works council in firm $(\text { WCINC })^{l}$ & 0.61 & 0.49 \\
\hline Interaction of $W C U D$ with $W C I N C^{1}$ & 41.39 & 34.16 \\
\hline Interaction $W C U D$ with dummy year 2003 & 28.18 & 29.70 \\
\hline Male & 0.55 & 0.50 \\
\hline Foreigner & 0.09 & 0.28 \\
\hline Part-time employment & 0.21 & 0.41 \\
\hline Age (in years) & 41.45 & 10.86 \\
\hline Tenure (in years) & 10.98 & 10.09 \\
\hline Apprenticeship & 0.63 & 0.48 \\
\hline University degree & 0.22 & 0.41 \\
\hline Prefers Social Democrats $(S P D)$ & 0.22 & 0.41 \\
\hline Prefers Christian Parties (CDU/CSU) & 0.18 & 0.38 \\
\hline Blue collar worker & 0.31 & 0.46 \\
\hline Father was self-employed & 0.11 & 0.31 \\
\hline Firm size: $20 \leq X<200$ employees & 0.29 & 0.45 \\
\hline Firm size: $200 \leq X<2000$ employees & 0.24 & 0.43 \\
\hline Firm size: $X \geq 200$ employees & 0.26 & 0.44 \\
\hline Agriculture/ hunting/ fishing & 0.01 & 0.08 \\
\hline Mining/ quarrying & 0.005 & 0.07 \\
\hline Manufacturing & 0.27 & 0.44 \\
\hline Electricity/ gas/ water supply & 0.01 & 0.09 \\
\hline Construction & 0.05 & 0.23 \\
\hline Wholesale and retail trade/ repair & 0.13 & 0.34 \\
\hline Hotels/ restaurants & 0.02 & 0.14 \\
\hline Transport, storage/ communication & 0.06 & 0.23 \\
\hline Financial intermediation & 0.05 & 0.22 \\
\hline Real estate/ renting/ business & 0.08 & 0.27 \\
\hline Public administration/ defence & 0.10 & 0.30 \\
\hline Education & 0.07 & 0.26 \\
\hline Health/ social work & 0.11 & 0.32 \\
\hline Other services/ Private households & 0.04 & 0.20 \\
\hline Berlin & 0.04 & 0.19 \\
\hline Schleswig-Holstein & 0.05 & 0.21 \\
\hline Hamburg & 0.02 & 0.16 \\
\hline Lower Saxony & 0.12 & 0.32 \\
\hline Bremen & 0.01 & 0.10 \\
\hline North Rhine-Westphalia & 0.27 & 0.45 \\
\hline Hessen & 0.08 & 0.28 \\
\hline Rhineland-Palatinate, Saarland & 0.06 & 0.25 \\
\hline Baden-Wuerttemberg & 0.16 & 0.37 \\
\hline Bavaria & 0.18 & 0.39 \\
\hline Year 2003 & 0.49 & 0.50 \\
\hline
\end{tabular}

Source: SOEP 2001 and 2003. Survey weights are used. N=14430. ${ }^{l}$ : year 2001 only. 
Table A.3: Simultaneous Equation Model:

Determinants of Works Councillorship in West Germany (2001)

\begin{tabular}{|c|c|c|}
\hline & \multicolumn{2}{|c|}{ Specification 1 (2001) } \\
\hline & $\begin{array}{l}\text { Parameter / } \\
\text { Std.-Err. }\end{array}$ & $\begin{array}{l}\text { Marginal } \\
\text { Effect }\end{array}$ \\
\hline Male & $\begin{array}{c}0.066 \\
(0.084)\end{array}$ & 0.044 \\
\hline Foreigner & $\begin{array}{l}0.419 * * \\
(0.142)\end{array}$ & -0.040 \\
\hline Part-time employment & $\begin{array}{l}-0.229 * \\
(0.113)\end{array}$ & -0.032 \\
\hline Age (in years) & $\begin{array}{l}0.113 * * * \\
(0.029)\end{array}$ & 0.014 \\
\hline Age squared (in years) & $\begin{array}{l}-0.001 * * * \\
(0.000)\end{array}$ & -0.000 \\
\hline Tenure (in years) & $\begin{array}{r}0.029 * \\
(0.014)\end{array}$ & 0.008 \\
\hline Tenure squared (in years) & $\begin{array}{l}-0.000 \\
(0.000)\end{array}$ & -0.000 \\
\hline Apprenticeship & $\begin{array}{l}0.360 * * \\
(0.110)\end{array}$ & 0.007 \\
\hline University degree & $\begin{array}{c}0.214 \\
(0.133)\end{array}$ & -0.054 \\
\hline Prefers Social Democrats $(S P D)$ & $\begin{array}{c}0.040 \\
(0.087)\end{array}$ & 0.093 \\
\hline Prefers Christian Parties (CDU/CSU) & $\begin{array}{l}-0.115 \\
(0.101)\end{array}$ & -0.021 \\
\hline Blue collar worker & $\begin{array}{c}0.109 \\
(0.099)\end{array}$ & 0.129 \\
\hline Father was self-employed & $\begin{array}{c}0.176 \\
(0.113)\end{array}$ & -0.038 \\
\hline Firm size: $20 \leq X<200$ employees & $\begin{array}{l}0.896^{* * *} \\
(0.130)\end{array}$ & 0.008 \\
\hline Firm size: $200 \leq X<2000$ employees & $\begin{array}{l}0.924 * * * \\
(0.146)\end{array}$ & 0.034 \\
\hline Firm size: $X \geq 200$ employees & $\begin{array}{l}0.912 * * * \\
(0.141)\end{array}$ & 0.100 \\
\hline Constant & $\begin{array}{l}-6.059 * * * \\
(0.687)\end{array}$ & \\
\hline $\begin{array}{l}\text { Industry dummies (NACE 1- digit) } \\
\text { State dummies }\end{array}$ & & \\
\hline $\begin{array}{l}\text { Wald-Test_X (degrees of freedom) } \\
\text { Wald-Test_ } \rho \text { (degrees of freedom) }\end{array}$ & $\begin{array}{r}1562 \\
11\end{array}$ & \\
\hline Number of Observations & & \\
\hline
\end{tabular}

Source: GSOEP 2001. Sample weights are used. Robust standard errors are in parentheses. Significance levels: ** $(0.01), *(0.05),+(0.1)$.

Wald_Test_X: $\mathrm{H}_{0}:$ no joint significance of all regressors. Wald-Test_ $\rho: \mathrm{H}_{0}: \rho=0$. Estimated parameters of the union membership equation are found in Table 3. 